Nadwa : Jurnal Pendidikan Islam

Vol. 12, Nomor 2 Tahun 2018

Accredited by Ristekdikti based on Decree No. 51/E/KPT/2017

\title{
The Search For Islamic Studies Information Through Smartphones By Visual Impairments Disability
}

\author{
Hanny Hafiar, \\ hanny.hafiar@unpad.ac.id \\ Padjadjaran University, Bandung, Indonesia \\ Priyo Subekti, \\ Padjadjaran University, Bandung, Indonesia

\section{Heru Riyanto Budiana} \\ Padjadjaran University, Bandung, Indonesia
}

\begin{abstract}
This study will find out the pattern of information retrieval about Islamic studies carried out by visual impairments people. This study uses a case study method. Respondents in this study were Muslim women with disabilities in the rehabilitation complex of the blind Wiyataguna, Bandung. The results showed that people with visual impairments used narrative sounds on their mobile phones to capture narrative voice abilities that were arranged at high speed. At first they used standard speed settings, but when the skill of capturing audio through the sense of hearing increased, they set the pace of the narrative to be very fast, so that other people had difficulty listening to it.

Keywords : information search; Islamic studies; persons with disabilities; visually impaired; smartphones;

Abstrak

Penelitian ini berusaha untuk mengetahui pola pengambilan informasi mengenai studi Islam yang dilakukan oleh orang yang mengalami gangguan penglihatan. Penelitian ini menggunakan metode studi kasus. Responden dalam penelitian ini adalah perempuan Muslim penyandang cacat yang berada di komplek rehabilitasi orang buta Wiyataguna, Bandung. Hasil penelitian menunjukkan bahwa orang-orang dengan gangguan penglihatan menggunakan suara naratif pada handphone untuk menangkap kemampuan suara naratif yang diatur dengan kecepatan tinggi. Pada mulanya mereka menggunakan pengaturan kecepatan standar, namun ketika keterampilan menangkap audio melalui indera pendengaran meningkat, mereka mengatur laju narasi menjadi sangat cepat, sehingga orang lain sulit untuk mendengarkannya.
\end{abstract}

Kata kunci: pencarian informasi, studi Islam, penyandang cacat, tunanetra, smartphone

IS SN 1979-1739 (P) ; ISSN 2502-8057 (E).

G 2018 Nadwa : Jurnal Pendidikan Islam | UnN Walisongo.

Accredited by Ristekdikti based on Decree No $51 / E / K P T / 2017$

http:/joumal. wal isongo ac.id/index.php'nadwa 


\section{Introduction}

There are many studies that examine the relationship between using smartphones and teenagers, among others: the use of smartphones that have cognitive functions 1 , the use of smartphones that have a significant influence on communication behavior2, the pathological impact of smartphone use 3 , and adolescent self-concept in connection with smartphone usage 4.

There have been many studies conducted on the relationship between blind people with the use of smartphone technology, among others: the use of various tools and special applications based on smartphones for the people with visually impaireds, using the google glass6, and using the addition of tools through the sense of touch and hearing ${ }_{7}$, through the use of smartphones in overcoming visual limitations of the people with visually

1 Wilmer, H. H., Sherman, L. E., \& Chein, J. M. Smartphones and Cognition: A Review of Research Exploring the Links between Mobile Technology Habits and Cognitive Functioning. Frontiers in Psychology, 2017, (1-16). https://doi.org/10.3389/fpsyg.2017.00605

2 Gifary, S., \& N Kurnia, I. Intensitas Penggunaan Smartphone Terhadap Perilaku Komunikasi. Jurnal Sosioteknologi, 2015, 14(2), 170. https://doi.org/10.1007/s13398-014-0173-7.2

3 Saidon, J., Musa, R., Harris, M., \& Harun, M. Pathological Smartphone Use and Its Consequences. Pertanika Journal of Social Sciences and Humanities, 2017, 25, 391-398.

4 Yuniati, Y., Yuningsih, A. N. I., \& Nurahmawati. Konsep Diri Remaja dalam Komunikasi Sosial melalui “ Smartphone ." Mimbar, Jurnal Sosial Dan Pembangunan, 2015, 31(2), 439-450.

5 Pratama, D., Hakim, D. A., Prasetya, Y., Febriandika, N. R., Trijati, M., \& Fadlilah, U. Rancang Bangun Alat dan Aplikasi untuk Para Penyandang Tunanetra Berbasis Smartphone Android. Khazanah Informatika: Jurnal Ilmu Komputer Dan Informatika, 2016, 2(1), 14-19.

6 Vokalova, A. Google Glass Used as Assistive Technology Its Utilization for Blind and Visually Impaired People Google Glass Used as Assistive (2017).

7 Banf, M., Mikalay, R., Watzke, B., \& Blanz, V. PictureSensation - a mobile application to help the blind explore the visual world through touch and sound. Journal of Rehabilitation and Assistive Technologies Engineering, 2016. 3, 1-10. https://doi.org/10.1177/2055668316674582. 
impaireds, to the use of smartphones in helping the learning process 9 .

In essence, these researches are research that examines the problems of contemporary communication related to the phenomenon of the development of information technology, which impacts on human social life, including the life of a group of individuals who experience obstacles in the ability of vision. On the other hand, the sense of sight is an important sensory which is required in using a smartphone that was initially designed to accommodate the needs of people without disability to communicate. Fortunately, today the development of communication technology has begun to make efforts to accommodate the needs of people who have unique characteristics, such as the blind.

Unlike people who can see who have more freedom to come to attend religious forums that present information to fill their spiritually, the opportunity for people with visual impairment to perform activities is not as wide as people due to visual limitations, mobility, and blind accessibility are also restricted if they want to attend religious studies, especially if the location of the study is remote, crowded, or held at the time after the dawn or evening, where public transport has not or is no longer available.

Therefore, this is where the role of smartphones, whose presence replaces face-to-face meetings without reducing the value of information they got. Blind people with disabilities can access information on Islamic studies through their smartphone, because with the help of sufficient quota or wifi network then the information, either in the form of text, audio, and audiovisual can be accessed and information of Islamic studies can be consumed easily through several alternative applications.

There is an interesting phenomenon to be observed in relation to the search for information on Islamic studies by people with

8 Sahasrabudhe, S., Singh, R., \& Heath, D. Innovative Affordances for Blind Smartphone Users : A Qualitative Study. Journal on Technology and Persons with Disabilities, 2016. 145-156.

9 Bülbül, M., Yiğit, N., \& Garip, B. Adapting smart phone applications about physics education to blind students. Journal of Physics: Conference Series, 2016. 707(1). https://doi.org/10.1088/1742-6596/707/1/012039 
disabilities because the habit of accessing religious information forms a separate information search pattern among people with visual impairment, which distinguishes the pattern of information seeking by awareness, especially Muslim women. If in the phenomenon of pilgrims who are not visually impaired, sometimes the physical appearance of ustadz or da'i become one attraction for them to continue to follow face-to-face study to access studies through smartphones. This differs from the blind worshipers because they cannot see the look of ustadz, or physically, because of their limited visual senses.

The research related to the use of smartphones and other Internet-based technology tools, with the aim to disseminate and enhance religious values, has been studied in connection a new style of Islamic da'wah 10 , and the use of technology as a propagation tool.11

Nonetheless, people with visual impairment also have a special search pattern relating to the needs of cognition and affection of spiritual splendor. Therefore, this study aims to examine the pattern of information search about Islamic studies through smartphones by visually impaired people.

There are several studies that examine the topics that come into contact with the current study, but the studies use different types of studies, such as the correlation test between the use of smartphones with learning achievement 12 , personality disorders associated with selfie $e_{13}$, the test of influence on social

10 Hidayat, A. S. Membangun Dimensi Baru Dakwah Islam: Dari Dakwah Tekstual menuju Dakwah Kontekstual. Jurnal Risalah, 2013. 24(2), 1-15. Retrieved from http://ejournal.uinsuska.ac.id/index.php/risalah/article/view/10.

11 Purwanto, Y., Taufik, M., \& Jatnika, A. W. Peran Teknologi Informasi Dalam Perkembangan Dakwah Mahasiswa. Jurnal Sosioteknologi, 2017. 16(1), 94-109.

12 Dewanti, T. C., Widada, \& Triyono. Hubungan Keterampilan Sosial Dan Penggunaan Gadget Smartphone Dengan Prestasi Belajar Siswa Sma Negeri 9 Malang. Jurnal Kajian Bimbingan Dan Konseling, 2016. 1(3), 126131. https://doi.org/10.17977/um001v1i32016p126

13 Anshori, H., Arianti, R., \& Rumaisa. Hubungan Minat Selfie Terhadap Kecenderungan Gangguan Kepribadian Narsistik Pada Siswa - Siswi Di SMPN 7 Kelas VII Banjarmasin. Laporan Penelitian, 2015. 1-16. Retrieved from idr.uin-antasari.ac.id/5302/2/RINGKASAN PENELITIAN.pdf 
development for early childhood, 14 explorative study of the student's awareness of smartphone usage 15 , influence on teenage association pattern 16 , or interpretive methods of health information searching ${ }_{17}$, accessibility to the information 18 , and accessibility of persons disability in information technology 19 . The research uses descriptive case study method.

The case itself relates to the pattern of information search about Islamic studies conducted by some Muslim women who live in the PSBN Wiyataguna Bandung, which is a special rehabilitation site for the blind. There are a number of informants selected purposively, i.e. Muslimah who actively follow the study and have a high intensity in accessing Islamic studies through smartphones.

\section{Results And Discussions}

Based on the results of data collection got from the field it knows it the interest of Muslimah with visual impairment to access information about Islamic studies is inseparable from the conditions and habits within the family and the influence of the peer group as a social friend. This interest in information on Islamic studies encourages them to have the motive of seeking

14 Sari, T. P., \& Mitsalia, A. A. Pengaruh Penggunaan Gadget Terhadap Personal Sosial Anak Usia Pra Sekolah Di TKIT AL Mukmin. Profesi, 2016. 13(2), 72-78.

15 Asuncion, J., Budd, J., Fichten, C. S., Nguyen, M., Barile, M., \& Amsel, R. Social Media Use By Students With Disabilities. Academic Exchange Quarterly, 2012. 16(1), 30-35. Retrieved from http://www.adaptech.org/pubs/AEQSocialMediaUse.pdf

16 Ihsan, M. Pengaruh Terapan Media Internet dan Pola Pergaulan. Tsamrah Al-Fikri, 2016. 10, 103-120.

17 Haryono, T. J. S., Kinasih, S. E., \& Mas'udah, S. Akses dan informasi bagi perempuan penyandang disabilitas dalam pelayanan kesehatan reproduksi dan seksualitas Access and information for disable women in reproduction and sexuality well-being services. Jurnal Masyrakat, Kebudayaan Dan Politik, 2013. 26(2), 65-79.

18 Syafi, M. Pemenuhan Aksesibilitas Bagi Penyandang Disabilitas. Jurnal Inklusi, 2014. I(2), 268-308.

19 Thohari, S. Pandangan Disabilitas dan Aksesibilitas Fasilitas Publik bagi Penyandang Disabilitas di Kota Malang. Indonesian Journal of Disabilities Studies, 2014. 1/1, 27-37. 
information by first learning how to access the information through a smartphone.

Some Muslim women state that a strong family environment with Islamic values is the foundation for them to always feel the need to learn Islam as a whole. This religious family environment also encourages them to follow religious studies, to meet and gather with fellow blind persons with similar interests. Friendship in the same spirit begins with a meeting in the same study event, or in a conversation, they consider that under the values held. It terms this with the terminology of a friend of the scholars. This confirms the opinion that the Family is the smallest unit of society, which serves as the first education for the child 20 . The results of the interview can be cited as follows:

"I come from a big family that has a boarding school, so since childhood, we used to study the science of religion. Especially I do feel the need to get closer to religion, so when in the dormitory or in the school environment I usually look for friends who also have an interest in the science of religion,"

As for the ability and skills of accessing information via smartphone, supported by the initial ability before experiencing blindness, or results from learning from fellow people with disabilities who have been adept at using the smartphone. Proficiency in using the smartphone in terms of completeness of special supporting applications for the blind on the gadget, or the ability to move your finger on the touchscreen smartphone, to capture the ability of narrative sound which is set with high speed. As following disclosed by ASR:

"I just experienced total blindness when I was 21, because previously although since childhood there are symptoms of blindness, I can still see, and also after experiencing blindness, I was operated and could see again, but eventually remain totally blind ... before the total blind, I

20 Khasanah, U. Analisis Praktik Pelibatan Orang Tua Dan Masyarakat Dalam Kegiatan Kreatif Anak Usia Dini: Studi Kasus di TK Pertiwi Ds.Tambah Rejo, Kec. Tunjungan Kab. Blora. Nadwa | Jurnal Pendidikan Islam, 2017. 11(2), 177-198. 
had time to use the phone, had also used the android phone, so I was already accustomed to using the mobile phone,"

People with visual impairment were visualized using a smartphone with narrative speed settings at the normal or standard speeds. But as their skills increase to capture audio through the sense of hearing, they set the pace of narration faster, so that if the people listening to the narration come from the smartphones belonging to the people with the visual impairment will feel that the narration played by their smartphone is difficult to follow because it is so quick, more like the sound of a duck.

"I experienced blindness as an adult, and gradually, so the process of my adaptation to a special application for the blind was longer than the friends who are from the beginning know the phone is in a state of blind, so their ability in operationalizing mobile phones and listen to the voice from talkback or screen reader which is set at high speed is more sophisticated because they are familiar with the setting, although the sound is set faster, than for ordinary people the sound that sounds will sound like a duck,"

Meanwhile, the search pattern of da'wah content through smartphone conducted by Muslimah with visual impairment comprising several types, namely: searching for da'wah content with audio file types, searching for da'wah content based on certain da'i, and searching for da'wah content based on topics to be known or studied. That is, modernization has also penetrated the world of da'wah21

Next, will appear two types of effects generated namely the understanding after deepening the information and not yet understand the full information. There is confusion within the visual impairment Muslim in accessing information, especially if it is related to fiqh so that sometimes they feel that the information presented by Ustadz A is different from Ustadz B. This condition will stimulate the desire to get clarity. In order to obtain the clarity, resource persons tended to take steps, among others: to ask about the clarity of the information in ustadz/ ustadzah in the

21 Suradi, A. Transformation Of Pesantren Traditions In Face The Globalization Era. Nadwa | Jurnal Pendidikan Islam, 2018. 12(1), 27-38. 
face-to-face study, for example in the mosque or in a recitation event in PSBN environment. Another step is to ask directly to da'i through question-and-answer facilities with site manager admin although not all questions responded quickly and satisfactorily by the admin. Any other step is to discuss with colleagues, families or parties they consider that being enlightening. One of the data that reinforces these findings, recorded in the following interviews:

"Sometimes I am often confused because now there is a lot of understanding or madhhab, there is a tight understanding and some are loose, maybe this includes khilafiyah, but I usually like to ask directly to the ustadz that I follow his ideology, to be clear and there is no doubt"

The result, after doing some of these steps, there is some source person who feels to be more understanding and get clarity, but some are actually even more confused. Not infrequently also the confusion that is felt due to the difference of opinion from da'i which their Islam study accessed through various applications in the smartphone that even raises skepticism in source person, so the intensity of information retrieval of Islamic studies that they do not as intense as before.

On the contrary, until then came the desire to share knowledge and Islamic values through verbal and nonverbal communication to people who are in the immediate environment. This is also the starting point for Muslimah with visual impairment became interested in accessing information about Islamic studies through smartphones. The scheme can be described as follows: 


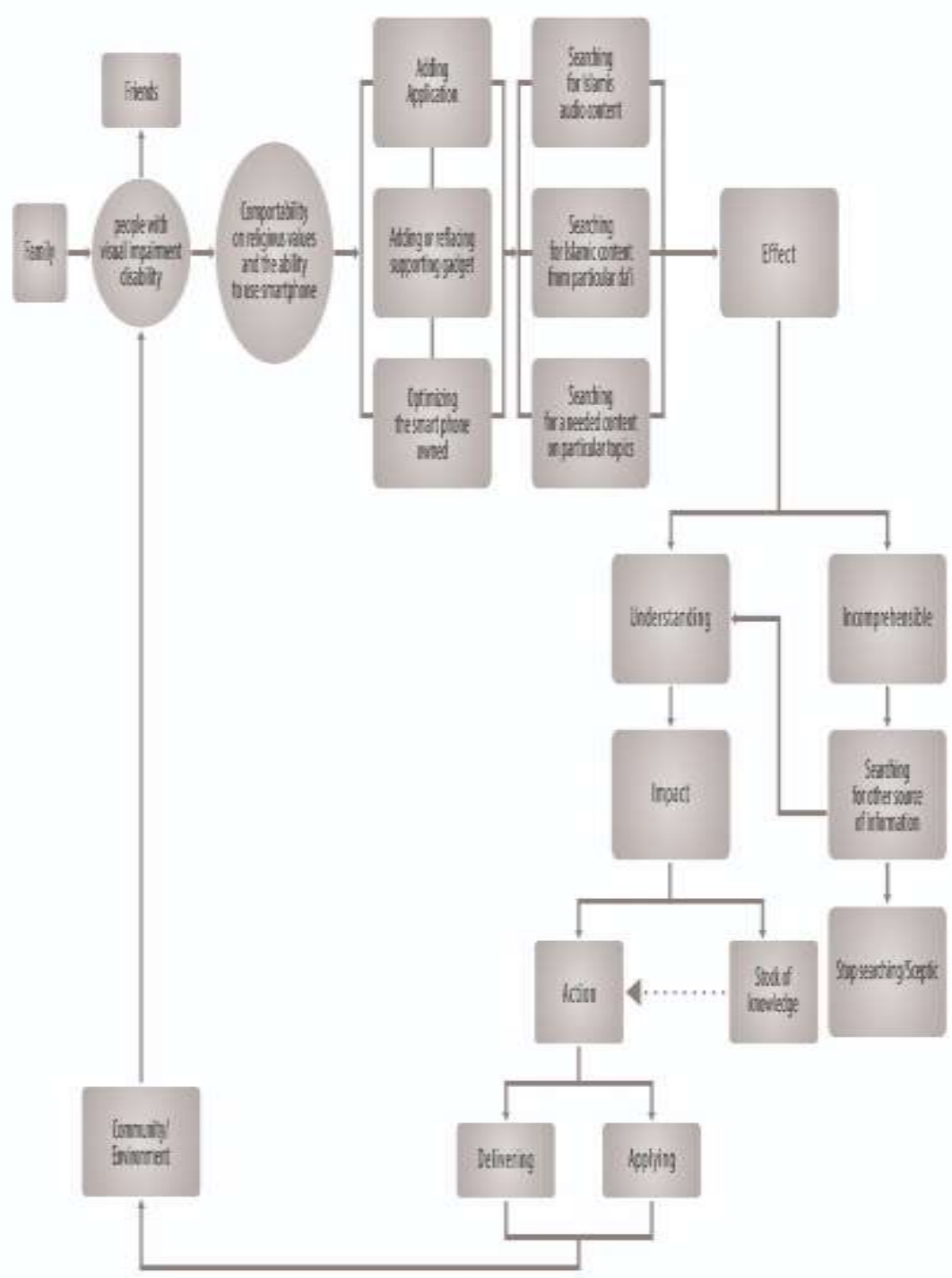

Figure 1. Model of The Search For Islamic Studies Information Through Smartphones By Visual Impairments Disability 
In principle, da'wah requires the ability to dig and encourage the audience to awaken awareness to meet the demands of religion $_{22}$. Therefore, the phenomenon of the use of media as a means of preaching is now increasing and evolving along with the acceleration of the development of communication technology 23. There is a statement that "the media as a propaganda medium has an economic motif while the preacher as a speaker needs a medium that can deliver his da'wah mission"24. This means that the smartphone as a medium is expected to be able to bridge the needs between da'i as the communicators and jamaah as the communicant. This is in accordance with the acknowledgment of the informant stating that:

"Alhamdulillah, nowadays to study the knowledge of religion is not always to be sought in school or boarding school, or study in mosque only. Nowadays with the spread of knowledge and da'wah through the mobile media, it helps us, especially for me in searching for religious knowledge ... I can not imagine if every week I have to take a study at a certain mosque away from home, ride public transport, so I occasionally take part in the study, only when there is a chance"

As in a research, the result stated that da'wah media; as a communication channel can be a mosque, school, reception, mobile phone, free speech, mass media and social media (internet, facebook, twitter, foursquare, LinkedIn, and BB) 25 . Through these statements can be seen that social media that can be accessed through smartphones can be used as a medium of da'wah and share information about Islamic studies. This is in line with the statement that "social media has become crucial platforms for information exchange, where people with

22 Ishaq, R. Dakwah di tengah industrialisasi media. Jurnal Komunikasi Islam, 2013. 3(1).

23 Khoiruzzaman, W. Urgensi dakwah media cyber berbasis peace journalism. Jurnal Ilmu Dakwah, 2016.36(2), 316-334.

24 Hidayat, Amri Syarif. "Membangun Dimensi Baru Dakwah Islam: Dari Dakwah Tekstual Menuju Dakwah Kontekstual.” Jurnal Risalah, 2013. 24 (2): 1-15. http://ejournal.uin-suska.ac.id/index.php/risalah/article/view/10.

25 Suharto. Urgensi komunikasi politik dakwah. Jurnal Dakwah Tabligh, 2013. 14(1), 25-34. 
disabilities can easily acquire information and interact with 26 , similar results were obtained from the studies that have the locus in Chinazr. The use of smartphone media by people with visually impaired was not only intended to seek information, they even also use it to disseminate information.

"If there is good info, sometimes I also share it to WA or FB group, so I can also share my religious knowledge with friends or the friends in my friend list, it can be quite a good reward to spread goodness to other people"

As for the use of social media which is widely used, refers to the results of the study, showing data that: The most common social media platforms were Facebook (76\%), Twitter (18\%), LinkedIn (16\%), Blogs (12\%), Google+ (4\%), and other (14\%). Youtube was mentioned by $50 \%$ of participants as well 28 . All the Muslimah with the visual impairment who are the resource persons in this study also have Facebook accounts, although some are active and less active in using them, as there is a tendency in this research that if they are active in a particular social media platform, it will be less active in other social media platforms. But essentially, resource persons are accustomed to using social media platforms to seek information or build an interaction with other parties.

However, although respondents have been able to use this platform, there are still some barriers, including social factors, limited English skills and limited access to computing devices 29. This condition, some can be overcome with the applications that

26 Raghavendra, P., Newman, L., Grace, E., \&, \& Wood, D. Enhancing social participation in young people with communication disabilities living in rural Australia: Outcomes of a home-based intervention for using social media. Disability and Rehabilitation, 2015. 37(17), 1576-1590.

27 Wang, W., Wu, Y. C. J., Yuan, C.-H., Xiong, H., \& Liu, W.-J. Use of Social Media in Uncovering Information Services for People with Disabilities in China. The International Review of Research in Open and Distributed Learning, 2017. 18(1). https://doi.org/10.19173/irrodl.v18i1.2621

28 Phuong, H. Social media engagement in the disability community: A Report for Indiana Disability Rights. Indiana Disability Rights. 2017

29 Vashistha, A., Cutrell, E., Dell, N., \& Anderson, R. Social Media Platforms for Low-Income Blind People in India. Proceedings of the 17th International ACM SIGACCESS Conference on Computers \& Accessibility ASSETS, 2015. 15, 259-272. https://doi.org/10.1145/2700648.2809858 
help and facilitate people with visual disabilities to remain able to use their smartphones optimally in accessing information. These applications include the TalkBack application that is used to provide ease to the visually impaired by using an Android smartphone that on average almost all android phones using touchscreen technologyзо. Furthermore, there are individuals and institutions that develop portable Braille devices that will allow individuals with visual impairments to read electronic documents by moving Braille text with fingers 31 .

Another helper application is PictureSensation which comes with a user interface that can guide swipe-based movements to allow self-use by blind users 32 . There are also applications that can turn graphics on the screen into hand-readable graphics 33 , as well as software capable of translating natural languages, including Arabic and English, into the Braille System and vice versa. The Braille system is the most widely used system for nonvisual 34 . These latest applications make it easier for people with visual impairment to still have a chance to access information on Islamic studies.

In fact, today, mass media is the most important element of globalization 35 . Through the internet, da'wah activities can be

30 Priyadi, E. Analisis aplikasi talkback bagi penyandang tunanetra pada operasi sistem android. Dokumen Karya Ilmiah Universitas Dian Nuswantoro Semarang. 2014

31 Arif, S. Electronic Braille Document Reader. Master Thesis. University of Huddersfield. 2013. Retrieved from http://eprints.hud.ac.uk/id/eprint/18089/

32 Banf, Michael, Ruben Mikalay, Baris Watzke, and Volker Blanz. "PictureSensation - a Mobile Application to Help the Blind Explore the Visual World through Touch and Sound." Journal of Rehabilitation and Assistive Technologies Engineering, 2016. 3: 1-10. doi:10.1177/2055668316674582.

33 Bülbül, M., N. Yiğit, and B. Garip. "Adapting Smart Phone Applications about Physics Education to Blind Students." Journal of Physics: Conference Series, 2016. 707 (1). doi:10.1088/1742-6596/707/1/012039.

34 Al-Salman, A. S. A Bi-directional Bi-Lingual Translation Braille-Text System. Journal of King Saud University - Computer and Information Sciences, 2008. 20, 13-29. https://doi.org/10.1016/S1319-1578(08)80002-X

35 Parwito, \& Drajat, K. T. Kontruksi Identitas Kultural Masyarakat Pluralis dalam Terpaan Masyarakat Globalisasi. Jurnal Mimbar, 2013. 29(1), 111-120. 
done by spreading Islamic information to millions of people around the world. If the internet is used for da'wah, then the target of da'wah (mad'u) can be millions of individuals connected by computer networks36, essentially, technology can be used for the benefit of da'wah37. The technological superiority of today's media industry should be used maximally in Islamic da'wah activities either by Islamic organizations, Islamic studies groups existing in societyss. Therefore, to meet the needs of communicators and communicants in sharing information Islamic studies, then the use of various platforms based on the Internet should be optimized.

\section{Conclusion}

People with visual impairments use narrative sounds on cellphones to capture narrative sound abilities that are arranged at high speed. They were visualized at first using smartphones initially using standard speed settings, but when the skill of capturing audio through the hearing senses increases, they regulate the pace of narration very quickly, so that other people find it difficult to listen.

Smartphone gadgets have a high level of relationship in an effort to increase the value of religiosity in a person, in this case, to study religion deeply, because at this time all kinds of information can be searched through Smartphone with support from other applications39. In addition, there are also researched results that mention that the positive impact of the perceived Internet is easy to communicate and get information fast and useful for the implementation of worship including prayer itself

36 Arifin, A. Dakwah Kontemporer Sebuah Studi Komunikasi,. Yogyakarta: Graha Ilmu. 2011.

37 Zaini, A. Media Teknologi Informasi Modern Sebagai Wasilah Dakwah. At-Tabsyir, Jurnal Komunikasi Penyiaran Islam, 2014. 2(Nomor 1), 57-72.

38 Juniawati. Dakwah melalui Media Elektronik: Peran dan Potensi Media Elektronik dalam Dakwah Islam di Kalimantan Barat. Jurnal Dakwah, 2014. XV(2), 211-233.

39 Kasetyaningsih, S. Pengaruh Aplikasi Islami di Gadget Terhadap Sisi Religiousitas Mahasiswa. Duta. Com, 2015. 9(September), 19-27. Retrieved from http://journal.stmikdb.ac.id/index.php/dutacom/article/view/9 
as articles about the science of the prayer procedure 40 . This means that the use of smartphones to access information of Islamic studies is already perceived by smartphone users, in this case including the Muslimah with the visual impairment who became the resource person in research, as stated by Asri as one of the resource persons who revealed that:"the search of da'wah material through mobile phone, allow me to spend time positively, as well as gain knowledge and useful knowledge, hopefully, can increase faith and improve my morals and behavior in the future".

\section{References}

Al-Salman, A. S. A Bi-directional Bi-Lingual Translation BrailleText System. Journal of King Saud University - Computer and Information Sciences, 2008. 20, 13-29. https://doi.org/10.1016/S1319-1578(08)80002-X

Anshori, H., Arianti, R., \& Rumaisa. Hubungan Minat Selfie Terhadap Kecenderungan Gangguan Kepribadian Narsistik Pada Siswa - Siswi Di SMPN 7 Kelas VII Banjarmasin. Laporan Penelitian, 2015. 1-16. Retrieved from idr.uinantasari.ac.id/5302/2/RINGKASAN PENELITIAN.pdf

Arif, S. Electronic Braille Document Reader. Master Thesis. University of Huddersfield. 2013. Retrieved from http://eprints.hud.ac.uk/id/eprint/18089/

Arifin, A. Dakwah Kontemporer Sebuah Studi Komunikasi,. Yogyakarta: Graha Ilmu. 2011.

Asuncion, J., Budd, J., Fichten, C. S., Nguyen, M., Barile, M., \& Amsel, R. Social Media Use By Students With Disabilities. Academic Exchange Quarterly, 2012. 16(1), 30-35. Retrieved from http://www.adaptech.org/pubs/AEQSocialMediaUse.pdf Banf, M., Mikalay, R., Watzke, B., \& Blanz, V. PictureSensation - a mobile application to help the blind explore the visual world through touch and sound. Journal of Rehabilitation and

40 Wahidin, A., Effendi, M. R., \& Shaleh, K. Pengaruh Penggunaan Internet Terhadap Religiusitas Mahasiswa Universitas Islam Bandung. Prosiding Komunikasi Penyiaran Islam, 2015. 17-24. 
Assistive Technologies Engineering, 2016. 3, 1-10. https://doi.org/10.1177/2055668316674582.

Banf, Michael, Ruben Mikalay, Baris Watzke, and Volker Blanz.

"PictureSensation - a Mobile Application to Help the Blind Explore the Visual World through Touch and Sound." Journal of Rehabilitation and Assistive Technologies Engineering, 2016.23 : 2 1doi:10.1177/2055668316674582.

Bülbül, M., N. Yiğit, and B. Garip. "Adapting Smart Phone Applications about Physics Education to Blind Students." Journal of Physics: Conference Series, 2016. 707 (1). doi:10.1088/1742-6596/707/1/012039.

Bülbül, M., Yiğit, N., \& Garip, B. Adapting smart phone applications about physics education to blind students. Journal of Physics: Conference Series, 2016. 707(1). https://doi.org/10.1088/1742-6596/707/1/012039

Dewanti, T. C., Widada, \& Triyono. Hubungan Keterampilan Sosial Dan Penggunaan Gadget Smartphone Dengan Prestasi Belajar Siswa Sma Negeri 9 Malang. Jurnal Kajian Bimbingan Dan Konseling, 2016. 1(3), 126-131. https://doi.org/10.17977/um001v1i32016p126

Gifary, S., \& N Kurnia, I. Intensitas Penggunaan Smartphone Terhadap Perilaku Komunikasi. Jurnal Sosioteknologi, 2015, 14(2), 170. https://doi.org/10.1007/s13398-014-0173-7.2

Haryono, T. J. S., Kinasih, S. E., \& Mas'udah, S. Akses dan informasi bagi perempuan penyandang disabilitas dalam pelayanan kesehatan reproduksi dan seksualitas Access and information for disable women in reproduction and sexuality well-being services. Jurnal Masyrakat, Kebudayaan Dan Politik, 2013. 26(2), 65-79.

Hidayat, A. S. Membangun Dimensi Baru Dakwah Islam: Dari Dakwah Tekstual menuju Dakwah Kontekstual. Jurnal Risalah, 2013. 24(2), 1-15. Retrieved from http://ejournal.uin-

suska.ac.id/index.php/risalah/article/view/10.

Hidayat, Amri Syarif. "Membangun Dimensi Baru Dakwah Islam: Dari Dakwah Tekstual Menuju Dakwah Kontekstual.” Jurnal Risalah, 2013. 24 (2): 1-15. http://ejournal.uinsuska.ac.id/index.php/risalah/article/view/10. 
Ihsan, M. Pengaruh Terapan Media Internet dan Pola Pergaulan. Tsamrah Al-Fikri, 2016. 10, 103-120.

Ishaq, R. Dakwah di tengah industrialisasi media. Jurnal Komunikasi Islam, 2013. 3(1).

Juniawati. Dakwah melalui Media Elektronik: Peran dan Potensi Media Elektronik dalam Dakwah Islam di Kalimantan Barat. Jurnal Dakwah, 2014. XV(2), 211-233.

Kasetyaningsih, S. Pengaruh Aplikasi Islami di Gadget Terhadap Sisi Religiousitas Mahasiswa. Duta. Com, 2015. 9(September), 19-27. Retrieved from http://journal.stmikdb.ac.id/index.php/dutacom/article/view/ 9

Khasanah, U. Analisis Praktik Pelibatan Orang Tua Dan Masyarakat Dalam Kegiatan Kreatif Anak Usia Dini : Studi Kasus di TK Pertiwi Ds.Tambah Rejo, Kec. Tunjungan Kab. Blora. Nadwa | Jurnal Pendidikan Islam, 2017. 11(2), 177198.

Khoiruzzaman, W. Urgensi dakwah media cyber berbasis peace journalism. Jurnal Ilmu Dakwah, 2016.36(2), 316-334.

Parwito, \& Drajat, K. T. Kontruksi Identitas Kultural Masyarakat Pluralis dalam Terpaan Masyarakat Globalisasi. Jurnal Mimbar, 2013. 29(1), 111-120.

Phuong, H. Social media engagement in the disability community: A Report for Indiana Disability Rights. Indiana Disability Rights. 2017

Pratama, D., Hakim, D. A., Prasetya, Y., Febriandika, N. R., Trijati, M., \& Fadlilah, U. Rancang Bangun Alat dan Aplikasi untuk Para Penyandang Tunanetra Berbasis Smartphone Android. Khazanah Informatika: Jurnal Ilmu Komputer Dan Informatika, 2016, 2(1), 14-19.

Priyadi, E. Analisis aplikasi talkback bagi penyandang tunanetra pada operasi sistem android. Dokumen Karya Ilmiah Universitas Dian Nuswantoro Semarang. 2014

Purwanto, Y., Taufik, M., \& Jatnika, A. W. Peran Teknologi Informasi Dalam Perkembangan Dakwah Mahasiswa. Jurnal Sosioteknologi, 2017. 16(1), 94-109.

Raghavendra, P., Newman, L., Grace, E., \&, \& Wood, D. Enhancing social participation in young people with communication disabilities living in rural Australia: 
Outcomes of a home-based intervention for using social media. Disability and Rehabilitation, 2015. 37(17), 15761590 .

Sahasrabudhe, S., Singh, R., \& Heath, D. Innovative Affordances for Blind Smartphone Users : A Qualitative Study. Journal on Technology and Persons with Disabilities, 2016. 145156.

Saidon, J., Musa, R., Harris, M., \& Harun, M. Pathological Smartphone Use and Its Consequences. Pertanika Journal of Social Sciences and Humanities, 2017, 25, 391-398.

Sari, T. P., \& Mitsalia, A. A. Pengaruh Penggunaan Gadget Terhadap Personal Sosial Anak Usia Pra Sekolah Di TKIT AL Mukmin. Profesi, 2016. 13(2), 72-78.

Suharto. Urgensi komunikasi politik dakwah. Jurnal Dakwah Tabligh, 2013. 14(1), 25-34.

Suradi, A. Transformation Of Pesantren Traditions In Face The Globalization Era. Nadwa | Jurnal Pendidikan Islam, 2018. 12(1), 27-38.

Syafi, M. Pemenuhan Aksesibilitas Bagi Penyandang Disabilitas. Jurnal Inklusi, 2014. I(2), 268-308.

Thohari, S. Pandangan Disabilitas dan Aksesibilitas Fasilitas Publik bagi Penyandang Disabilitas di Kota Malang. Indonesian Journal of Disabilities Studies, 2014. 1/1, 27-37.

Vashistha, A., Cutrell, E., Dell, N., \& Anderson, R. Social Media Platforms for Low-Income Blind People in India. Proceedings of the 17th International ACM SIGACCESS Conference on Computers \& Accessibility - ASSETS, 2015. 15, 259-272. https://doi.org/10.1145/2700648.2809858

Vokalova, A. Google Glass Used as Assistive Technology Its Utilization for Blind and Visually Impaired People Google Glass Used as Assistive (2017).

Wahidin, A., Effendi, M. R., \& Shaleh, K. Pengaruh Penggunaan Internet Terhadap Religiusitas Mahasiswa Universitas Islam Bandung. Prosiding Komunikasi Penyiaran Islam, 2015. 1724.

Wang, W., Wu, Y. C. J., Yuan, C.-H., Xiong, H., \& Liu, W.-J. Use of Social Media in Uncovering Information Services for People with Disabilities in China. The International Review 
of Research in Open and Distributed Learning, 2017. 18(1). https://doi.org/10.19173/irrodl.v18i1.2621

Wilmer, H. H., Sherman, L. E., \& Chein, J. M. Smartphones and Cognition: A Review of Research Exploring the Links between Mobile Technology Habits and Cognitive Functioning. Frontiers in Psychology, 2017, (1-16). https://doi.org/10.3389/fpsyg.2017.00605

Yuniati, Y., Yuningsih, A. N. I., \& Nurahmawati. Konsep Diri Remaja dalam Komunikasi Sosial melalui " Smartphone ." Mimbar, Jurnal Sosial Dan Pembangunan, 2015, 31(2), 439450.

Zaini, A. Media Teknologi Informasi Modern Sebagai Wasilah Dakwah. At-Tabsyir, Jurnal Komunikasi Penyiaran Islam, 2014. 2(Nomor 1), 57-72. 